\title{
Taxonomic Classification, Characterization and Mapping of BSP Farm of Parbhani for Rational Land Use Planning
}

\author{
S. S. Shilewant*, V. D. Patil and P. H. Gourkhede \\ Department of Soil Science and Agriculture Chemistry, Vasantrao Naik Marathwada Krishi \\ Vidyapeeth, Parbhani, 431401, Maharashtra, India \\ *Corresponding author
}

\section{A B S T R A C T}

\begin{tabular}{|l|}
\hline Key w o r d s \\
Taxonomic \\
classification, \\
Mapping, Land use \\
pattern, Thematic \\
map, Soil etc
\end{tabular}

Taxonomical Classification, Characterization and Mapping of BSP Farm (Khanapur Block-B) for Rational Land Use Planning, MKV, Parbhani was carried out during the year 2012. The total gross area of college farm is spread over 135.49 ha and it is divided into four blocks viz. Block A, B, C and D. These four blocks were surveyed by traversing along the bunds of farm plots and the data on natural resources were collected. From these 110 soil samples were drawn to study the properties and nutrient status. Further the two representative soil profiles were excavated on the basis of soil depth and behavior of cracks. The thematic maps of all important soil parameters were generated. The results emerged out from the present investigation revealed that soils of BSP Farm (Khanapur Block-B) Typic Haplusterts (40\%), Vertic Ustochrerts (36\%) and Lithic Ustorthents (24\%). These soils are dark brown to black in colour and clay in texture. These soils are slightly to moderately alkaline in nature, safe in total soluble salt concentration, moderately calcareous to calcareous and moderately high supply with organic carbon. Typic Haplusterts have higher alkalinity than rest of the great groups. The soils of BSP farm (Khanapur block-B) are deep to shallow and dominate in Typic Haplusterts (23 plots) followed by Vertic Ustochrerts (19 plots) and Lithic Ustorthents (13 plots). According to Munsell colour chart these soils are dark brown to black in colour. While, the bulk density of soils ranged from 1.30 to $1.48 \mathrm{Mgm}^{-3}$. The Entisols had higher bulk density than the Vertisols and Entisols. All soils are having clay texture derived from fine crystalline extrusive basalt rocks. The soils are slightly alkaline ( 72 per cent) to moderately alkaline ( 38 per cent) in reaction. Among these three soil groups Vertic Ustochrepts showed higher $\mathrm{pH}$ than rest of soil groups. The soils are safe in total soluble salt concentration. These soils are only 3 percent slightly calcareous, 45 percent moderately calcareous and 52 percent calcareous in nature. The soils $\mathrm{pH}, \mathrm{EC}$ and $\mathrm{CaCO}_{3}$ content was increased with depth. Soils content low to high in organic carbon. The VerticUstochrerts show lower organic carbon than TypicHaplusterts and Lithic Ustorthents. The thematic maps of important soil properties were generated, which are useful for better understanding and developing the location specific crop production technology on spatial basis of BSP farm (Khanapur Block-B).

\section{Introduction}

Soil resource information plays a vital role in the management of natural resources and more specifically in the field of agriculture. Soil is a dynamic non-renewable natural resource whose proper husbandry is essential for both continued agriculture productivity and to prevent its degradation. To maintain the present level of soil productivity and meet the food, fodder needs and shelter demand of future management of soil resources on specific principles is of prime important (Sarkar et al., 2002). Soil is considered to be a store house of plant nutrient even though there is continuous removal by intensive 
cropping and losses through leaching and erosion which depleted content to great extent. Soil mapping is the process of classifying soil type and other soil properties in a given area and geo-encoding such information.

To achieve sustainable yields of crops besides maintaining soil health needs knowledge on morphological, physical and chemical characteristics and classification of soils which is essential requirement (www. Google.com/soil mapping and LUP).

More than ever before, there is a renewed attention being given to soils, which form a part of the environment, as knowledge and understanding of soils is either limited or is not being exploited for practical applications. Sustainable management practices are to be developed to feed and bring prosperity to the people depending on the limited natural resource base.

However, no development plan can be successful unless it is based on reliable knowledge on the extent of different kinds of soils in relation to climate, vegetation and potential crop production, and how best this finite natural resource is managed for the benefit of the existing and future generations.

Land use planning help the farmer to participate in scientific inquiry and to construct logical conclusion which is based on evidence. The modern geospatial technologies such as Remote sensing (RS), Geographic Information System (GIS), Global Positioning System (GPS) and Information Technology (IT) offer immense potential for land and water resources development and management (Das et al., 2009).

Land use planning evaluates land and alternative land use patterns for the purpose of selecting the best choice. Planning decisions deal sometimes with interest of competing land users and may therefore be questioned and/or criticized. Resource management activities concern basically soil and water conservation.

Agriculture land- use means land under net sown area, follow land and uncultivated land excluding fallow land. The cultivated area is known as net sown area, which is also known as agriculture land. (Todkari et al., 2010) Thus, soil resource thematic map and using data various soil properties and soil profile studies will focus light on the BSP farm soils of M.K.V., Parbhani.

Till to date no effort are made in mapping of BSP farm (Khanapur Block-B) soils in general and fertility status in particular. Mapping of farm or agril research station is needed for making developmental farm; it is a basic source for utilization as economical management. Therefore it was planned to map the farm. The emerged thematic maps will serve as a base for management of soils, crops and selection of other activity related to soil.

\section{Materials and Methods}

The soil, a natural resource even today is less understood and less recognized in comparison to plant and animals. The soil, an unconsolidated mineral matter on the surface of the earth, is influenced by parent material, climate, micro and macro organisms, topography and time.

Various soils forming factors and processes influence the variations in characteristics of different soils. In the present project efforts have been made to describe soils of BSP farm (Khanapur block-B), MKV Parbhani. Geographically The BSP farm (Khanapur Block- $B$ ) is situated at $409 \mathrm{~m}$ above mean sea level between $19^{\circ} 18^{\prime} \mathrm{N}$ latitude and $76^{\circ} 47^{\prime} \mathrm{E}$ longitude. 
The total area of BSP farm (Khanapur Block$B)$ is 135.49 ha. and its area is distributed in A, B, C and D Blocks. Climate of Parbhani district is characterized by hot and dry in summer and cold in winter agro climatically it is classified as assured rainfall zone. The BSP farm (Khanapur Block - B), Parbhani is supported with the variety of natural trees and shrubs which includes Neem, Acacia, Australian babul and Mango.

The site was selected From UPRS and CCBP farm of MKV, Parbhani. The BSP farm (Khanapur Block-B) is spread over 135.49 net cultivated area. The soil samples were collected by digging the pit up to $0-15 \mathrm{~cm}$ depth as per procedure of guarding the soil and rejecting half of it, near about $500 \mathrm{gm}$. Nearly about 110 samples were collected from BSP Farm (Khanapur Block-B) Parbhani Collected soil samples were dried, pounded in wooden mortar and pastel and were passed through $2 \mathrm{~mm}$ sieve. Each sample was thoroughly mixed to make it homogenous and preserved in properly labeled polythene bags for a laboratory analysis (for determination of bulk density and free $\mathrm{CaCO}_{3}$, soil samples were retained before pounding the soil). In all 110 representative surface soil samples were collected from 55 plots by adopting standard procedure outlined by Yadav and Khanna (1979).

\section{Results and Discussion}

\section{Taxonomic classification of soils}

Surveyed soil samples from BSP Farm (Khanapur Block-B), Parbhani, were placed as per USDA Classification system (Malewar, 1986). From Table 1, it was observed that out of 110 samples, 44(40\%), were deep soils, 41 (36\%) were medium deep soils and 26 (24\%) were shallow (Fig. 1).

\section{Physical and physico-chemical properties of soil}

\section{Physical properties of soil}

Soil physical property have a great impact on its use and behavior towards the plant growth. The support of the growing plant, its root penetration and microbial activity in rhizosphere is influenced by physical condition of soil. Some important properties of soil viz. soil texture, soil colour and bulk density of soils of BSP farm (Khanapur block- B) are evaluated in the present investigation and analytical data are presented in Table 2. All soils of the BSP farm (Khanapur Block -B) showed hue i.e. 7.5YR and 10YR, there was little variation in value and chroma.

The value varies between 2.5 to 5 while purity of colour i.e. chroma fluctuate between 1 to 4 . So according to Munsell colour system these soils are dark brown to black in colour. Very dark grey, brown to black colour dominate in inceptisol, very dark brown to brown noticed in Entisol. In Vertisol soil colour was very dark grayish brown to very dark gray to black. This variation in colour value and chroma may be because of assemblage of minerals derives from basaltic trap rock. Its dark brown to black colour is associated with Titaniferrous composition and humus content.

The bulk density of soils ranged from 1.30 to $1.48 \mathrm{Mgm}^{-3}$. The Entisols had higher bulk density than the Vertisols and Entisols. The soil texture was determined by feel method and reported in Table 2 revealed that all the soils were clay in texture. Fine clay texture of these soils is due to the fine crystalline extrusive basaltic rock. The basalt rock is formed due to rapid cooling of molten magma and result into fine crystallization. On weathering these rocks produce fine texture clay soils. 


\section{Physico-chemical properties of soil}

The data on physico-chemical properties of BSP farm (Khanapur Block -B) soils viz. pH, $\mathrm{EC}, \mathrm{CaCO}_{3}$ and organic carbon content are presented in Table $3 \mathrm{pH}$ of the soils ranged from 7.38 to 8.39 with an average of 7.92 . The higher $\mathrm{pH}$ of soils was found in plot no. C-3-2 in sample second, whereas lowest $\mathrm{pH}$ was noted in plot B-4-3. The electrical conductivity of soil was in the range of 0.14 to $1.37 \mathrm{dSm}^{-1}$ with an average of $0.28 \mathrm{dSm}^{-1}$. The highest EC was recorded in third sample of plot no. D-4-10. However the lowest EC was recorded in plot no. B-4-3.The variation in organic carbon content was recorded in the different plots of BSP farm (Khanapur Block $-B)$. It was ranged from 2.18 to $10.97 \mathrm{gkg}^{-1}$ with an average of $7.61 \mathrm{~g} \mathrm{~kg}^{-1}$ (Fig. 2).

Range and average values of physicochemical properties of different soil groups

Physico-chemical properties (range and average) of BSP Farm (Khanapur Block -B), MKV Parbhani distributed in different taxonomic soil groups are presented in Table 4. The soils of three soil groups showed variation in $\mathrm{pH}$, free lime and organic carbon and little variation in EC. The $\mathrm{pH}$ of soils of TypicHaplusterts, VerticUstochreptsand LithicUstorthents was in the range of 7.71 8.30, 7.53- 8.39 and 7.38-8.05, respectively. The average of $\mathrm{pH}$ of soils was observed to be $7.97,7.95$ and 7.79 , respectively.

These results clearly indicated that all soil are slightly to moderately alkaline in reaction. Among these three soil groups VerticUstochrepts showed higher $\mathrm{pH}$ than rest of soil groups. This alkaline $\mathrm{pH}$ of these soils may be because of basic soil parent material derived from basalt rock. The EC of soils of TypicHaplusterts, VerticUstochrepts and LithicUstorthents was in the range of 0.18$1.37, \quad 0.15-0.45$ and $0.14-0.38 \mathrm{dSm}^{-1}$, respectively. The average of EC of soils was observed to be $0.34,0.26$ and $0.23 \mathrm{dSm}^{-1}$, respectively. On average basis TypicHaplusterts showed higher salt accumulations. Organic carbon is a single important factor for soil which influences physical, chemical and biological properties.

All the three soil groups of BSP farm (Khanapur Block-B) were moderately supplied with organic carbon. The average organic carbon content of three soil groups (Table 4) was $7.55,7.43$ and $8.02 \mathrm{~g} \mathrm{~kg}^{-1}$, in TypicHaplusterts, Vertic Ustochreptsand Lithic Ustorthents, respectively (Fig. 3).

Free lime content noticed in various soil groups was distributed between $15-82 \mathrm{~g} \mathrm{~kg}^{-1}$ in Vertisols, 17.4 to $84 \mathrm{~g} \mathrm{~kg}^{-1}$ in Inceptisols and $21-82 \mathrm{~g} \mathrm{~kg}^{-1}$ in Entisols with an average 52.51, 54.22 and 52.31. The data on lime content revealed that Inceptisols had higher $\mathrm{CaCO}_{3}$ as compared to other two soil groups.

Categorization of soils on the basis of ratings of $\mathrm{pH}, \mathrm{EC}, \mathrm{CaCO}_{3}$ and organic carbon content

Categorization of BSP Farm (Khanapur Block- $B$ ) soils on the basis of accepted rating of various physico-chemical properties is presented in Table 5.

Out of 110 samples, 72 samples (65.45 per cent) were slightly alkaline in nature and 38 samples (34.55 per cent) were moderately alkaline. As regard to different soil groups, it was evidenced that out of 44 samples of TypicHalpusterts 20 samples were moderately alkaline, in reaction; rest 24 samples were slightly alkaline in reaction. 16 samples of VerticUstrochrepts were moderately alkaline while other 24 samples were slightly alkaline in reaction. In case of Lithic Ustorthents 2 samples were moderately alkaline and 24 samples were slightly alkaline in nature. 
Out of 110 samples 108 samples are safe in salt concentration and two samples are normal in salt concentration. Two samples from TypicHalpusterts were normal in salt concentration and others 42 samples are safe in salt concentration. Soil samples from other two groups are safe in salt concentration.

Organic carbon content was found to be low to high. Out of total plots, 13.64 per cent plots were low, 29.55 per cent were moderate and 47.73 per cent were moderately high and 17.27 per cent soil samples were high in organic carbon content. Six samples from TypicHalpusterts were low in organic carbon content, 12 samples were moderate, 21 samples were moderately high and four samples were high in organic carbon content. Seven samples of VerticUstrochrepts were low, 14 samples were medium, 15 samples were moderately high and 4 samples were high in organic carbon content.

In case of Lithic Ustorthents 10 samples were high in organic carbon, 9 samples were moderately high and seven samples were medium in organic carbon content. On the basis of free $\mathrm{CaCO}_{3}$ content out of 110 soil samples in various soil groups 3 soil samples (2.73 per cent) are slightly calcareous, 50 soil samples (45.45 per cent) were moderately calcareous and 57soil samples(51.82 per cent) were calcareous in nature.

Thus from Table 5 it was inferred that soil of BSP farm (Khanapur Block-B), MKV, Parbhani were slightly to moderately alkaline in reaction. TypicHaplusterts and VerticUstochrepts showed higher $\mathrm{pH}$ than Lithic Ustorthents.

This soil showing $\mathrm{pH}$ more than 7.5 that shows dominance of basic salts with impart the alkalinity to the soil solution. These salts are released during the decomposition of basalt rock that is dominant in ferromagnesium mineral. The alkaline $\mathrm{pHs}$ of the soils from basalt trap are also reported by Vasekar (2001), Yadav (2005) and Bodhale (2007). Nearly 98.18 per cent soil samples were found to be a safe in total soluble salt concentration and 1.82 per cent soil samples were normal in total soluble salt concentration.

The findings recorded were in agreement with the Ghuge, (2002). These soil were moderately supplied with organic carbon. The low content of organic carbon in soil may be attributed to the mechanical scrapping of surface layer of soil, during the leveling and due to the lower magnitude of FYM application which further aggrevated by high temperature. The high temperature is responsible for oxidation of organic carbon from soil to carbon dioxide.

The reduction in organic carbon content in soil over period of time is reported by Yadav (2005) and Vasekar (2001). The finding observed in Soniya et al., (2010). All the soil samples were slightly to calcareous in nature. The two calcareous soil forming parameters are ferromagnesium mineral and sub-tropical climate tends to develop calcareous soils.

This is supposed to be one liming factors for successful crop production. The studies showed that the chlorosis phenomenon in calcareous soil is associated with conversion of iron and zinc in to unavailable or precipited of calcium carbonate (Kanwar and Randhawa, 1960). The similar findings were also reported by Medhe et al., (2012) and Waghmare et al., (2008) (Fig. 4 and 5).

\section{Thematic maps}

The thematic maps of important soil properties were brought out by the rating provided by Parker (1951) and Jones (1980). These thematic maps showed important soil 
properties and its spatial distribution of the BSP farm (Khanapur Block-B). Thematic maps of important soil properties viz. $\mathrm{pH}, \mathrm{EC}$, free $\mathrm{CaCO}_{3}$ organic carbon were brought out by using MS office software and coral draw.The BSP Farm (Khanapur Block-B) MKV, Parbhani is spread over 135.49 ha area it is divided into 58 blocks in C-4-2, C-4-3 and C-4-4 were under sugarcane crop cultivation.

The map of soil $\mathrm{pH}$ of BSP farm, MKV, Parbhani depicted that 20 plots were moderately alkaline in soil reaction and 23 plots were slightly alkaline in reaction. The plot under moderately alkaline reaction needs immediate reclamation measures. It is evidence from all plots of farm are safe in total soluble salt concentration. So there is no restriction for cultivation of crop in respect of salt concentration. Out of 55 plots 23 plots are moderately calcareous in nature and 22 plots are calcareous in nature of BSP farm (Khanapur Block-B) showed. Due to calcareous nature of the soil and its accumulation at subsurface level impose restriction while selection of crop. The organic carbon status of BSP farm is shown. It is observed that some plots low (A-3-1, A4-1, A-4-3, B-4-2 and D-3-6) and rest of the plots were moderate to high in organic carbon. It is proposed to apply organic manures, composts to raise the organic carbon content of soil.

These thematic maps will be useful for better understanding and developing the location specific crop production technology. From the results depicted through various thematic maps it is inferred that the all plots of BSP Farm (Khanapur Block- B) MKV, Parbhani electrical conductivity of soils BSP Farm (Khanapur Block- B) are safe. All plots of farm are well supplied with organic carbon.

Table.1 Taxonomic classification of soils

\begin{tabular}{|c|c|c|c|}
\hline $\begin{array}{l}\text { Sr. } \\
\text { No. }\end{array}$ & Soil groups & $\begin{array}{c}\text { Total } \\
\text { samples }\end{array}$ & Number of plots in each soil group \\
\hline 1 & $\begin{array}{c}\text { TypicHapluster } \\
\text { ts }\end{array}$ & $\begin{array}{c}44 \text { samples } \\
\text { (23 plots) }\end{array}$ & $\begin{array}{l}\text { A-3-1, B-3-3, B-3-4, B-4-7, B-4-8, B-4-9, C- } \\
\text { 3-5, C-3-6, C-4-5, C-4-8, C-4-9, C-4-10. D-3- } \\
\text { 3, D-3-4, D-3-5, D-3-6, D-4-2, D-4-3, D-4-4, } \\
\text { D-4-5, D-4-6, D-4-9, D-4-10. }\end{array}$ \\
\hline 2 & $\begin{array}{l}\text { VerticUstochre } \\
\text { pts }\end{array}$ & $\begin{array}{l}\text { 40samples } \\
\text { (19 plots) }\end{array}$ & $\begin{array}{l}\text { A-4-1, A-4-2, A-4-3, A-4-7, B-3-2, B-4-1, B- } \\
\text { 4-2, B-4-6, B-4-10, B-4-13, C-3-1, C-3-2, C- } \\
\text { 3-3, C-4-1, C-4-6, C-4-7, D-3-1, D-4-7, D-4- } \\
\text { 8. }\end{array}$ \\
\hline 3 & $\begin{array}{c}\text { Lithic } \\
\text { Ustorthents }\end{array}$ & $\begin{array}{c}26 \text { samples } \\
\text { (13 plots) }\end{array}$ & $\begin{array}{l}\text { A-3-2, A-4-4, A-4-5, A-4-6, B-3-1,B-4-3, B- } \\
\text { 4-4, B-4-5, B-4-11, B-4-12, C-3-4, D-3-2, D- } \\
\text { 4-1. }\end{array}$ \\
\hline
\end{tabular}


Table.2 Soil physical characteristics of BSP farm (Khanapur Block-B)

\begin{tabular}{|c|c|c|c|c|c|c|}
\hline $\begin{array}{l}\text { Sr. } \\
\text { No. }\end{array}$ & Plot no. & Sample no. & $\begin{array}{l}\text { Soil } \\
\text { texture }\end{array}$ & $\begin{array}{c}\text { Bulk density } \\
\left(\mathrm{Mgm}^{-3}\right)\end{array}$ & Soil colour & \begin{tabular}{|l|} 
Munsell \\
Colour \\
notation
\end{tabular} \\
\hline & & & \multicolumn{4}{|c|}{ TypicHaplusterts } \\
\hline 1 & A-3-1 & A-3-1-S & Clay & 1.34 & $\begin{array}{l}\text { Dark grayish } \\
\text { brown }\end{array}$ & $10 \mathrm{YR} 4 / 2$ \\
\hline 2 & & A-3-1-S $S_{2}$ & Clay & 1.41 & $\begin{array}{l}\text { Dark grayish } \\
\text { brown }\end{array}$ & $10 Y R 4 / 2$ \\
\hline 3 & & A-3-1-S 3 & Clay & 1.32 & Very dark gray & 7.5YR 3/1 \\
\hline 4 & B-3-3 & B-3-3- $\mathrm{S}_{1}$ & Clay & 1.35 & Brown & $7.5 \mathrm{YR} 4 / 2$ \\
\hline 5 & B-3-4 & B-3-4- $S_{1}$ & Clay & 1.41 & Black & 7.5YR $2.5 / 1$ \\
\hline 6 & B-4-7 & B-4-7- $S_{1}$ & Clay & 1.36 & Very dark gray & 7.5YR 3/1 \\
\hline 7 & & B-4-7- $S_{2}$ & Clay & 1.33 & Black & 7.5YR 2.5/1 \\
\hline 8 & B-4-8 & B-4-8- $S_{1}$ & Clay & 1.43 & Black & 7.5YR $2.5 / 1$ \\
\hline 9 & & B-4-8- $S_{2}$ & Clay & 1.44 & Black & 7.5YR 2.5/1 \\
\hline 10 & B-4-9 & B-4-9- $S_{1}$ & Clay & 1.31 & Very dark gray & 7.5YR 3/1 \\
\hline 11 & & B-4-9- $S_{2}$ & Clay & 1.32 & Very dark gray & 7.5YR 3/1 \\
\hline 12 & $C-3-5$ & C-3-5- $S_{1}$ & Clay & 1.39 & Very dark gray & 7.5YR 3/1 \\
\hline 13 & & C-3-5- $S_{2}$ & Clay & 1.34 & Black & 7.5YR $2.5 / 1$ \\
\hline 14 & C-3-6 & C-3-6- $S_{1}$ & Clay & 1.32 & Dark brown & 10YR $3 / 2$ \\
\hline 15 & & C-3-6- $\mathrm{S}_{2}$ & Clay & 1.36 & Black & 7.5YR $2.5 / 1$ \\
\hline 16 & $C-4-5$ & C-4-5- $\mathrm{S}_{1}$ & Clay & 1.35 & Very dark gray & 7.5YR 3/1 \\
\hline 17 & C-4-8 & C-4-8- $S_{1}$ & Clay & 1.37 & Very dark gray & 7.5YR 3/1 \\
\hline 18 & C-4-9 & C-4-9- $S_{1}$ & Clay & 1.44 & Black & 7.5YR 2.5/1 \\
\hline 19 & & C-4-9- $\mathrm{S}_{2}$ & Clay & 1.40 & Very dark gray & 7.5YR 3/1 \\
\hline 20 & C-4-10 & C-4-10-S 1 & Clay & 1.35 & Black & 7.5YR 2.5/1 \\
\hline 21 & & C-4- $10-S_{2}$ & Clay & 1.37 & Black & 7.5YR 2.5/1 \\
\hline 22 & D-3-3 & D-3-3- $S_{1}$ & Clay & 1.34 & Black & 7.5YR 2.5/1 \\
\hline 23 & & D-3-3- $S_{2}$ & Clay & 1.39 & Very dark gray & 7.5YR 3/1 \\
\hline 24 & D-3-4 & D-3-4- $S_{1}$ & Clay & 1.44 & Dark gray & 7.5YR 4/1 \\
\hline 25 & & D-3-4- $S_{2}$ & Clay & 1.32 & Very dark gray & 7.5YR 3/1 \\
\hline 26 & & D-3-4- $S_{3}$ & Clay & 1.40 & Black & 7.5YR 2.5/1 \\
\hline 27 & D-3-5 & D-3-5- $S_{1}$ & Clay & 1.37 & Very dark gray & 7.5YR 3/1 \\
\hline 28 & & D-3-5- $S_{2}$ & Clay & 1.34 & Very dark gray & 7.5YR 3/1 \\
\hline 29 & D-3-6 & D-3-6- $S_{1}$ & Clay & 1.38 & Black & 7.5YR 2.5/1 \\
\hline 30 & & D-3-6- $S_{2}$ & Clay & 1.37 & Black & 7.5YR 2.5/1 \\
\hline 31 & & D-3-6- $S_{3}$ & Clay & 1.33 & Black & 7.5YR 2.5/1 \\
\hline 32 & D-4-2 & D-4-2- $S_{1}$ & Clay & 1.34 & Very dark gray & 7.5YR 3/1 \\
\hline 33 & & D-4-2- $S_{2}$ & Clay & 1.37 & Black & 7.5YR 2.5/1 \\
\hline 34 & D-4-3 & D-4-3- $S_{1}$ & Clay & 1.39 & Black & 7.5YR 2.5/1 \\
\hline 35 & & D-4-3- $S_{2}$ & Clay & 1.43 & Black & 7.5YR 2.5/1 \\
\hline 36 & D-4-4 & D-4-4- $S_{1}$ & Clay & 1.36 & Black & 7.5YR $2.5 / 1$ \\
\hline
\end{tabular}




\begin{tabular}{|c|c|c|c|c|c|c|}
\hline 37 & & D-4-4- $S_{2}$ & Clay & 1.38 & Black & $7.5 \mathrm{YR} 2.5 / 1$ \\
\hline 38 & D-4-5 & $D-4-5-S_{1}$ & Clay & 1.45 & Very dark gray & 7.5YR 3/1 \\
\hline 39 & D-4-6 & D-4-6- $S_{1}$ & Clay & 1.35 & Dark gray & 7.5YR 4/1 \\
\hline 40 & D-4-9 & D-4-9- $S_{1}$ & Clay & 1.39 & Black & 7.5YR 2.5/1 \\
\hline 41 & & D-4-9- $S_{2}$ & Clay & 1.38 & Black & 7.5YR 2.5/1 \\
\hline 42 & D-4-10 & D-4-10- $S_{1}$ & Clay & 1.46 & Black & 7.5YR 2.5/1 \\
\hline 43 & & D-4-10- $S_{2}$ & Clay & 1.40 & Black & 7.5YR 2.5/1 \\
\hline 44 & & D-4-10- $S_{3}$ & Clay & 1.39 & Black & 7.5YR 2.5/1 \\
\hline 45 & & Average & & 1.38 & & \\
\hline & & & \multicolumn{4}{|c|}{ VerticUstochrerts } \\
\hline 46 & A-4-1 & A-4-1-S & Clay & 1.35 & Very dark gray & 7.5YR 3/1 \\
\hline 47 & & A-4-1-S & Clay & 1.36 & Brown & $7.5 \mathrm{YR} 4 / 3$ \\
\hline 48 & & A-4-1-S & Clay & 1.38 & Brown & $7.5 \mathrm{YR} 4 / 3$ \\
\hline 49 & & A-4-1-S & Clay & 1.39 & Very dark gray & 7.5YR 3/1 \\
\hline 50 & A-4-2 & A-4-2-S & Clay & 1.31 & Brown & $7.5 \mathrm{YR} 4 / 3$ \\
\hline 51 & & $\mathrm{~A}-4-2-\mathrm{S}_{2}$ & Clay & 1.32 & Very dark gray & 7.5YR 3/1 \\
\hline 52 & & $\mathrm{~A}-4-2-\mathrm{S}_{3}$ & Clay & 1.36 & Very dark gray & 7.5YR 3/1 \\
\hline 53 & A-4-3 & A-4-3-S & Clay & 1.48 & Brown & $7.5 \mathrm{YR} 4 / 3$ \\
\hline 54 & & $\mathrm{~A}-4-3-\mathrm{S}_{2}$ & Clay & 1.43 & Grayish brown & $10 Y R 5 / 2$ \\
\hline 55 & A-4-7 & A-4-7-S & Clay & 1.37 & Black & 7.5YR 2.5/1 \\
\hline 56 & & A-4-7-S $S_{2}$ & Clay & 1.36 & Very darkgray & 7.5YR 3/1 \\
\hline 57 & & A-4-7-S 3 & Clay & 1.39 & Black & 7.5YR 2.5/1 \\
\hline 58 & B-3-2 & B-3-2- $S_{1}$ & Clay & 1.37 & $\begin{array}{l}\text { Very Dark } \\
\text { grayish brown }\end{array}$ & 10YR $3 / 2$ \\
\hline 59 & & B-3-2- $\mathrm{S}_{2}$ & Clay & 1.34 & $\begin{array}{l}\text { Very dark } \\
\text { Brown }\end{array}$ & $7.5 Y R 2.5 / 2$ \\
\hline 60 & B-4-1 & B-4-1- $S_{1}$ & Clay & 1.41 & Very dark gray & 7.5YR 3/1 \\
\hline 61 & B-4-2 & B-4-2- $S_{1}$ & Clay & 1.39 & Brown & $7.5 \mathrm{YR} 4 / 2$ \\
\hline 62 & B-4-6 & B-4-6- $S_{1}$ & Clay & 1.42 & Dark brown & 7.5YR 3/2 \\
\hline 63 & & B-4-6- $S_{2}$ & Clay & 1.39 & $\begin{array}{l}\text { Dark grayish } \\
\text { brown }\end{array}$ & 10YR 4/2 \\
\hline 64 & & B-4-6- $S_{3}$ & Clay & 1.41 & Brown & $7.5 \mathrm{YR} 4 / 3$ \\
\hline 65 & & B-4-6- $S_{4}$ & Clay & 1.38 & Dark brown & $7.5 \mathrm{YR} 3 / 2$ \\
\hline 66 & B-4-10 & B-4-10-S & Clay & 1.37 & Brown & $7.5 \mathrm{YR} 4 / 3$ \\
\hline 67 & & B-4-10-S 2 & Clay & 1.44 & $\begin{array}{l}\text { Very dark } \\
\text { grayish brown }\end{array}$ & 10YR $3 / 2$ \\
\hline 68 & B-4-13 & B-4-13-S & Clay & 1.45 & $\begin{array}{c}\text { Very dark } \\
\text { grayish brown }\end{array}$ & 10YR 3/2 \\
\hline 69 & C-3-1 & C-3-1- $S_{1}$ & Clay & 1.34 & Black & 7.5YR 2.5/1 \\
\hline 70 & & C-3-1- $S_{2}$ & Clay & 1.31 & Black & 7.5YR 2.5/1 \\
\hline 71 & C-3-2 & C-3-2- $S_{1}$ & Clay & 1.36 & Very dark gray & 7.5YR 3/1 \\
\hline 72 & & C-3-2- $S_{2}$ & Clay & 1.42 & Very dark gray & 7.5YR 3/1 \\
\hline 73 & C-3-3 & C-3-3- $S_{1}$ & Clay & 1.32 & Very dark gray & 7.5YR 3/1 \\
\hline 74 & & C-3-3- $S_{2}$ & Clay & 1.33 & Very dark gray & 7.5YR 3/1 \\
\hline
\end{tabular}




\begin{tabular}{|c|c|c|c|c|c|c|}
\hline 75 & C-4-1 & C-4-1- $S_{1}$ & Clay & 1.39 & Black & 7.5YR $2.5 / 1$ \\
\hline 76 & & C-4-1- $S_{2}$ & Clay & 1.37 & Brown & $7.5 \mathrm{YR} 4 / 2$ \\
\hline 77 & & C-4-1- $S_{3}$ & Clay & 1.42 & Black & 7.5YR $2.5 / 1$ \\
\hline 78 & $C-4-6$ & C-4-6- $S_{1}$ & Clay & 1.43 & Dark brown & 7.5YR 3/2 \\
\hline 79 & & C-4-6- $S_{2}$ & Clay & 1.39 & Very dark gray & 7.5YR 3/1 \\
\hline 80 & C-4-7 & C-4-7- $S_{1}$ & Clay & 1.38 & Black & 7.5YR 2.5/1 \\
\hline $81^{\circ}$ & & C- $4-7-S_{2}$ & Clay & 1.36 & Very dark gray & 7.5YR 3/1 \\
\hline 82 & D-3-1 & D-3-1- $S_{1}$ & Clay & 1.36 & Black & 7.5YR $2.5 / 1$ \\
\hline 83 & & $D-3-1-S_{2}$ & Clay & 1.38 & Black & 7.5YR 2.5/1 \\
\hline 84 & D-4-7 & D-4-7- $S_{1}$ & Clay & 1.34 & Very dark gray & 7.5YR 3/1 \\
\hline 85 & D-4-8 & D-4-8- $S_{1}$ & Clay & 1.37 & Black & 7.5YR $2.5 / 1$ \\
\hline 86 & Average & & & 1.37 & & \\
\hline & & \multicolumn{5}{|c|}{ Lithic Ustorthents } \\
\hline 88 & A-3-2 & A-3-2-S & Clay & 1.36 & $\begin{array}{l}\text { Very Dark } \\
\text { grayish brown }\end{array}$ & 10YR $3 / 2$ \\
\hline 89 & & A-3-2-S 2 & Clay & 1.42 & Dark gray & 7.5YR 4/1 \\
\hline 90 & & A-3-2-S 3 & Clay & 1.45 & Very dark gray & 7.5YR 3/1 \\
\hline 91 & A-4-4 & A-4-4-S & Clay & 1.42 & Brown & $7.5 \mathrm{YR} 4 / 3$ \\
\hline 92 & A-4-5 & A-4-5-S & Clay & 1.39 & Very dark brown & 7.5YR $2.5 / 2$ \\
\hline 93 & & A-4-5-S 2 & Clay & 1.37 & Black & 7.5YR $2.5 / 1$ \\
\hline 94 & & A-4-5-S 3 & Clay & 1.38 & Brown & $7.5 \mathrm{YR} 4 / 3$ \\
\hline 95 & A-4-6 & A-4-6-S ${ }_{1}$ & Clay & 1.46 & $\begin{array}{l}\text { Very dark } \\
\text { brown }\end{array}$ & 7.5YR $2.5 / 2$ \\
\hline 96 & & A-4-6-S 2 & Clay & 1.42 & Dark brown & 7.5YR $3 / 2$ \\
\hline 97 & & $\mathrm{~A}-4-6-\mathrm{S}_{3}$ & Clay & 1.40 & Brown & $7.5 \mathrm{YR} 4 / 3$ \\
\hline 98 & & A-4-6-S 4 & Clay & 1.45 & Brown & $7.5 \mathrm{YR} 4 / 2$ \\
\hline 99 & B-3-1 & B-3-1- $S_{1}$ & Clay & 1.30 & Brown & 7.5YR 4/3 \\
\hline 100 & & B-3-1- $S_{2}$ & Clay & 1.35 & Dark brown & 7.5YR 3/2 \\
\hline 101 & & B-3-1- $S_{3}$ & Clay & 1.38 & Very dark gray & 7.5YR 3/1 \\
\hline 102 & B-4-3 & B-4-3- $S_{1}$ & Clay & 1.34 & Brown & $7.5 \mathrm{YR} 4 / 3$ \\
\hline 103 & B-4-4 & B-4-4- $S_{1}$ & Clay & 1.37 & Brown & 7.5YR 4/4 \\
\hline 104 & B-4-5 & B-4-5- $S_{1}$ & Clay & 1.40 & Very dark brown & 7.5 YR $2.5 / 2$ \\
\hline 105 & B-4-11 & B-4-11-S & Clay & 1.36 & Dark brown & 7.5YR $3 / 2$ \\
\hline 106 & & B-4-11-S & Clay & 1.38 & Dark brown & 7.5YR $3 / 2$ \\
\hline 107 & B-4-12 & B-4-12-S & Clay & 1.34 & Very dark brown & 7.5YR $2.5 / 2$ \\
\hline 108 & C-3-4 & C-3-4- $S_{1}$ & Clay & 1.40 & Black & 7.5YR 2.5/1 \\
\hline 109 & & C-3-4- $S_{2}$ & Clay & 1.41 & Black & 7.5YR 2.5/1 \\
\hline 110 & D-3-2 & D-3-2- $S_{1}$ & Clay & 1.35 & Very dark gray & 7.5YR 3/1 \\
\hline 111 & & $D-3-2-S_{2}$ & Clay & 1.37 & Very dark gray & 7.5YR 3/1 \\
\hline 112 & D-4-1 & D-4-1- $S_{1}$ & Clay & 1.35 & Black & 7.5YR 2.5/1 \\
\hline 113 & & D-4-1- $S_{2}$ & Clay & 1.32 & Black & 7.5YR 2.5/1 \\
\hline 114 & & Average & & 1.39 & & \\
\hline 115 & \multicolumn{2}{|c|}{ Total average } & & 1.38 & & \\
\hline
\end{tabular}


Table.3 Physico-chemical properties of BSP farm (Khanapur Block- B) Soil

\begin{tabular}{|c|c|c|c|c|c|c|}
\hline $\begin{array}{l}\text { Sr. } \\
\text { No. }\end{array}$ & Plot no. & Sample no. & $\begin{array}{l}\text { pH } \\
(1: 2.5)\end{array}$ & $\begin{array}{l}\mathrm{EC} \\
\left(\mathrm{dSm}^{-1}\right)\end{array}$ & $\begin{array}{l}\text { Organic } \\
\text { Carbon } \\
\left(\mathrm{gkg}^{-1}\right)\end{array}$ & $\begin{array}{l}\mathrm{CaCO}_{3} \\
\left(\mathrm{gkg}^{-1}\right)\end{array}$ \\
\hline & & & \multicolumn{4}{|c|}{ Typic Haplusterts } \\
\hline 1 & \multirow[t]{2}{*}{ A-3-1 } & A-3-1-S & 7.81 & 0.19 & 4.6 & 72 \\
\hline 2 & & A-3-1-S & 7.90 & 0.18 & 3.8 & 34 \\
\hline 3 & & A-3-1-S & 7.82 & 0.28 & 2.5 & 52 \\
\hline 4 & B-3-3 & B-3-3- $S_{1}$ & 7.92 & 0.28 & 5.14 & 53 \\
\hline 5 & B-3-4 & B-3-4- $\mathrm{S}_{1}$ & 7.97 & 0.26 & 6.98 & 41 \\
\hline 6 & \multirow[t]{2}{*}{ B-4-7 } & B-4-7- $S_{1}$ & 8.11 & 0.36 & 7.97 & 69 \\
\hline 7 & & B-4-7- $S_{2}$ & 7.75 & 0.18 & 9.97 & 40 \\
\hline 8 & \multirow[t]{2}{*}{ B-4-8 } & B-4-8- $S_{1}$ & 8.01 & 0.43 & 5.98 & 66 \\
\hline 9 & & B-4-8- $\mathrm{S}_{2}$ & 8.04 & 0.44 & 4.36 & 48 \\
\hline 10 & \multirow[t]{2}{*}{ B-4-9 } & B-4-9- $S_{1}$ & 7.81 & 0.31 & 8.70 & 70 \\
\hline 11 & & B-4-9- $\mathrm{S}_{2}$ & 7.9 & 0.32 & 6.2 & 41 \\
\hline 12 & \multirow[t]{2}{*}{$C-3-5$} & C-3-5- $S_{1}$ & 8.23 & 0.31 & 3.17 & 79 \\
\hline 13 & & C-3-5- $\mathrm{S}_{2}$ & 8.06 & 0.24 & 5.19 & 71 \\
\hline 14 & \multirow{2}{*}{ C-3-6 } & C-3-6- $S_{1}$ & 8 & 0.21 & 5.57 & 47 \\
\hline 15 & & C-3-6- $\mathrm{S}_{2}$ & 7.99 & 0.26 & 6.84 & 49 \\
\hline 16 & C-4-5 & $C-4-5-S_{1}$ & 8.04 & 0.24 & 7.87 & 73 \\
\hline 17 & C-4-8 & C-4-8- $S_{1}$ & 8.1 & 0.22 & 5.81 & 40 \\
\hline 18 & \multirow[t]{2}{*}{ C-4-9 } & C-4-9- $S_{1}$ & 8.16 & 0.28 & 6.75 & 65 \\
\hline 19 & & C-4-9- $\mathrm{S}_{2}$ & 8 & 0.26 & 7.38 & 62 \\
\hline 20 & \multirow[t]{2}{*}{ C-4-10 } & C-4-10- $S_{1}$ & 8.1 & 0.31 & 3.79 & 47 \\
\hline 21 & & C-4-10- $\mathrm{S}_{2}$ & 7.97 & 0.30 & 5.98 & 26 \\
\hline 22 & \multirow[t]{2}{*}{ D-3-3 } & D-3-3- $S_{1}$ & 8.24 & 1.34 & 5.37 & 81 \\
\hline 23 & & D-3-3- $S_{2}$ & 8 & 0.30 & 6.67 & 43 \\
\hline 24 & \multirow{3}{*}{ D-3-4 } & D-3-4- $S_{1}$ & 8.14 & 0.44 & 6.97 & 25 \\
\hline 25 & & D-3-4- $S_{2}$ & 7.92 & 0.31 & 7.98 & 30 \\
\hline 26 & & D-3-4- $S_{3}$ & 8.28 & 0.60 & 5.78 & 15 \\
\hline 27 & \multirow[t]{2}{*}{ D-3-5 } & D-3-5- $S_{1}$ & 7.86 & 0.23 & 6.38 & 25 \\
\hline 28 & & D-3-5- $S_{2}$ & 7.85 & 0.24 & 7.37 & 19 \\
\hline 29 & \multirow[t]{3}{*}{ D-3-6 } & D-3-6- $S_{1}$ & 7.87 & 0.34 & 2.18 & 82 \\
\hline 30 & & D-3-6- $S_{2}$ & 7.83 & 0.27 & 4.39 & 56 \\
\hline 31 & & D-3-6- $S_{3}$ & 7.79 & 0.24 & 3.99 & 39 \\
\hline 32 & \multirow[t]{2}{*}{ D-4-2 } & D-4-2- $S_{1}$ & 7.76 & 0.24 & 4.98 & 59 \\
\hline 33 & & D-4-2- $S_{2}$ & 7.93 & 0.37 & 6.78 & 81 \\
\hline 34 & \multirow[t]{2}{*}{ D-4-3 } & D-4-3- $S_{1}$ & 8.03 & 0.24 & 5.98 & 69 \\
\hline 35 & & D-4-3- $S_{2}$ & 8.00 & 0.22 & 7.98 & 21 \\
\hline 36 & \multirow[t]{2}{*}{ D-4-4 } & D-4-4- $S_{1}$ & 8.20 & 0.26 & 6.58 & 77 \\
\hline 37 & & D-4-4- $S_{2}$ & 8.30 & 0.28 & 7.67 & 80 \\
\hline 38 & D-4-5 & D-4-5- $S_{1}$ & 7.71 & 0.18 & 9.77 & 55 \\
\hline 39 & & D-4-6- $S_{1}$ & 7.76 & 0.21 & 9.37 & 50 \\
\hline 40 & \multirow[t]{2}{*}{ D-4-9 } & D-4-9- $S_{1}$ & 7.73 & 0.24 & 7.76 & 23 \\
\hline 41 & & D-4-9- $S_{2}$ & 7.96 & 0.38 & 7.57 & 65 \\
\hline
\end{tabular}




\begin{tabular}{|c|c|c|c|c|c|c|}
\hline 42 & \multirow[t]{3}{*}{ D-4-10 } & D-4-10- $S_{1}$ & 7.89 & 0.30 & 7.39 & 78 \\
\hline 43 & & D-4-10- $S_{2}$ & 7.95 & 0.41 & 7.76 & 42 \\
\hline 44 & & D-4-10- $S_{3}$ & 8.1 & 1.37 & 6.75 & 51 \\
\hline \multirow[t]{2}{*}{45} & & Average & 7.97 & 0.34 & 6.78 & 52.51 \\
\hline & & & \multicolumn{4}{|c|}{ VerticUstochrepts } \\
\hline 45 & \multirow[t]{4}{*}{ A-4-1 } & A-4-1-S & 7.97 & 0.25 & 3.7 & 64 \\
\hline 46 & & $\mathrm{~A}-4-1-\mathrm{S}_{2}$ & 8.00 & 0.32 & 3.1 & 36 \\
\hline 47 & & $\mathrm{~A}-4-1-\mathrm{S}_{3}$ & 7.93 & 0.26 & 4.9 & 30 \\
\hline 48 & & A-4-1-S 4 & 7.82 & 0.21 & 3.8 & 45 \\
\hline 49 & \multirow[t]{3}{*}{ A-4-2 } & $\mathrm{A}-4-2-\mathrm{S}_{1}$ & 8.01 & 0.31 & 5.7 & 84 \\
\hline 50 & & $\mathrm{~A}-4-2-\mathrm{S}_{2}$ & 7.95 & 0.25 & 6.2 & 82 \\
\hline 51 & & $\mathrm{~A}-4-2-\mathrm{S}_{3}$ & 7.96 & 0.26 & 7.1 & 34 \\
\hline 52 & \multirow[t]{2}{*}{ A-4-3 } & $A-4-3-S_{1}$ & 8.02 & 0.29 & 3.8 & 72 \\
\hline 53 & & $A-4-3-S_{2}$ & 7.96 & 0.24 & 2.3 & 56 \\
\hline 54 & \multirow[t]{3}{*}{ A-4-7 } & A-4-7-S & 7.92 & 0.23 & 4.7 & 60 \\
\hline 55 & & $\mathrm{~A}-4-7-\mathrm{S}_{2}$ & 8.00 & 0.45 & 5.7 & 78 \\
\hline 56 & & $\mathrm{~A}-4-7-\mathrm{S}_{3}$ & 7.95 & 0.27 & 5.9 & 56 \\
\hline 57 & \multirow[t]{2}{*}{ B-3-2 } & B-3-2- $S_{1}$ & 7.94 & 0.22 & 6.09 & 68 \\
\hline 58 & & B-3-2- $S_{2}$ & 7.89 & 0.25 & 7.04 & 23 \\
\hline 59 & B-4-1 & B-4-1- $S_{1}$ & 7.95 & 0.25 & 6.8 & 23 \\
\hline 60 & B-4-2 & B-4-2- $S_{1}$ & 8.12 & 0.29 & 3.4 & 41 \\
\hline 61 & \multirow[t]{4}{*}{ B-4-6 } & B-4-6- $S_{1}$ & 7.72 & 0.21 & 8.87 & 68 \\
\hline 62 & & B-4-6- $S_{2}$ & 7.9 & 0.23 & 7.5 & 62 \\
\hline 63 & & B-4-6- $S_{3}$ & 7.99 & 0.24 & 6.4 & 79 \\
\hline 64 & & B-4-6- $S_{4}$ & 8.01 & 0.28 & 5.56 & 36 \\
\hline 67 & \multirow[t]{2}{*}{ B-4-10 } & B-4-10- $S_{1}$ & 7.87 & 0.28 & 6.98 & 82 \\
\hline 68 & & B-4-10- $S_{2}$ & 7.53 & 0.21 & 9.4 & 63 \\
\hline 69 & B-4-13 & B-4-13-S & 7.53 & 0.15 & 9.08 & 31 \\
\hline 70 & \multirow{2}{*}{ C-3-1 } & C-3-1- $S_{1}$ & 8.24 & 0.34 & 4.97 & 40 \\
\hline 71 & & C-3-1- $S_{2}$ & 8.09 & 0.21 & 6.9 & 43 \\
\hline 72 & \multirow[t]{2}{*}{ C-3-2 } & C-3-2- $S_{1}$ & 8.2 & 0.26 & 4.34 & 61 \\
\hline 73 & & C-3-2- $\mathrm{S}_{2}$ & 8.39 & 0.41 & 3.71 & 58 \\
\hline 74 & \multirow[t]{2}{*}{$\mathrm{C}-3-3$} & C-3-3- $S_{1}$ & 7.96 & 0.22 & 6.98 & 46 \\
\hline 75 & & C-3-3- $\mathrm{S}_{2}$ & 8 & 0.24 & 7.09 & 41 \\
\hline 76 & \multirow[t]{3}{*}{ C-4-1 } & C-4-1- $S_{1}$ & 7.89 & 0.25 & 5 & 65 \\
\hline 77 & & C-4-1- $S_{2}$ & 8 & 0.27 & 6.07 & 82 \\
\hline 78 & & C-4-1- $\mathrm{S}_{3}$ & 8.06 & 0.31 & 5.9 & 52 \\
\hline 79 & \multirow[t]{2}{*}{ C-4-6 } & C-4-6- $S_{1}$ & 7.92 & 0.21 & 7.1 & 41 \\
\hline 80 & & C-4-6- $\mathrm{S}_{2}$ & 8.01 & 0.24 & 7.8 & 48 \\
\hline 81 & \multirow[t]{2}{*}{ C-4-7 } & C-4-7- $S_{1}$ & 8.06 & 0.28 & 5.54 & 81 \\
\hline 82 & & C-4-7- $\mathrm{S}_{2}$ & 7.9 & 0.20 & 6.84 & 52 \\
\hline 83 & \multirow[t]{2}{*}{ D-3-1 } & D-3-1- $S_{1}$ & 7.68 & 0.26 & 6.98 & 49 \\
\hline 84 & & D-3-1- $S_{2}$ & 7.95 & 0.28 & 5.94 & 7.4 \\
\hline 85 & D-4-7 & D-4-7- $S_{1}$ & 8.08 & 0.28 & 6.97 & 71 \\
\hline 86 & D-4-8 & D-4-8- $S_{1}$ & 7.68 & 0.22 & 9.57 & 48 \\
\hline \multirow[t]{2}{*}{87} & & Average & 7.95 & 0.26 & 6.68 & 54.22 \\
\hline & & \multicolumn{5}{|c|}{ Lithic Ustorthents } \\
\hline
\end{tabular}




\begin{tabular}{|c|c|c|c|c|c|c|}
\hline 88 & \multirow[t]{3}{*}{ A-3-2 } & A-3-2-S & 7.80 & 0.38 & 7.1 & 31 \\
\hline 89 & & A-3-2-S 2 & 7.93 & 0.27 & 5.9 & 78 \\
\hline 90 & & A-3-2-S & 7.91 & 0.24 & 5.7 & 59 \\
\hline 91 & A-4-4 & A-4-4-S & 7.97 & 0.29 & 6.5 & 64 \\
\hline 92 & \multirow{3}{*}{ A-4-5 } & $A-4-5-S_{1}$ & 8.01 & 0.31 & 5.3 & 81 \\
\hline 93 & & $A-4-5-S_{2}$ & 7.84 & 0.20 & 6.6 & 72 \\
\hline 94 & & $A-4-5-S_{3}$ & 7.93 & 0.25 & 5.8 & 50 \\
\hline 95 & A-4-6 & A-4-6-S & 7.73 & 0.23 & 9.9 & 34 \\
\hline 96 & \multirow{6}{*}{ B-3-1 } & A-4-6-S 2 & 7.53 & 0.17 & 9.1 & 30 \\
\hline 97 & & $A-4-6-S_{3}$ & 7.76 & 0.24 & 8.3 & 29 \\
\hline 98 & & A-4-6-S 4 & 7.86 & 0.21 & 7.4 & 57 \\
\hline 99 & & B-3-1- $\mathrm{S}_{1}$ & 7.9 & 0.19 & 5.9 & 82 \\
\hline 100 & & B-3-1- $\mathrm{S}_{2}$ & 7.72 & 0.18 & 8.97 & 30 \\
\hline 101 & & B-3-1- $S_{3}$ & 7.81 & 0.21 & 8.5 & 41 \\
\hline 102 & B-4-3 & B-4-3- $S_{1}$ & 7.38 & 0.14 & 9.4 & 43 \\
\hline 103 & B-4-4 & B-4-4- $S_{1}$ & 7.66 & 0.18 & 8.3 & 52 \\
\hline 104 & B-4-5 & B-4-5- $S_{1}$ & 7.68 & 0.19 & 7.80 & 38 \\
\hline 105 & \multirow[t]{2}{*}{ B-4-11 } & B-4-11- $S_{1}$ & 7.51 & 0.18 & 8.78 & 62 \\
\hline 106 & & B-4-11- $S_{2}$ & 7.88 & 0.28 & 7.98 & 67 \\
\hline 107 & B-4-12 & B-4-12- $S_{1}$ & 7.5 & 0.19 & 9.08 & 44 \\
\hline 108 & \multirow[t]{2}{*}{$C-3-4$} & C-3-4- $S_{1}$ & 7.9 & 0.20 & 8.17 & 29 \\
\hline 109 & & C-3-4- $\mathrm{S}_{2}$ & 7.84 & 0.21 & 6.21 & 50 \\
\hline 110 & \multirow[t]{2}{*}{ D-3-2 } & D-3-2- $S_{1}$ & 7.99 & 0.26 & 6.09 & 71 \\
\hline 111 & & D-3-2- $S_{2}$ & 8.05 & 0.27 & 5.71 & 80 \\
\hline 112 & \multirow[t]{2}{*}{ D-4-1 } & D-4-1- $S_{1}$ & 7.5 & 0.21 & 5.98 & 11 \\
\hline 113 & & D-4-1- $S_{2}$ & 7.87 & 0.22 & 7.97 & 65 \\
\hline 114 & & Average & 7.79 & 0.23 & 7.40 & 52.31 \\
\hline 115 & \multicolumn{2}{|c|}{ Total average } & 7.92 & 0.27 & 6.89 & 53.17 \\
\hline
\end{tabular}

Free calcium carbonate content of soil was found to be lowest in plot no. D-3-4 at third sample (15 $\left.\mathrm{g} \mathrm{kg}^{-1}\right)$ whereas highest calcium carbonate content was noticed in first sample $\left(84 \mathrm{~g} \mathrm{~kg}^{-1}\right)$ of plot no. A-4-2.

The average lime content in these soils was $53.17 \mathrm{~g} \mathrm{~kg}^{-1}$.

Table.4 Range and average values of physico- chemical properties of different soil groups of BSP Farm (Khanapur Block -B), MKV Parbhani

\begin{tabular}{|c|c|c|c|c|c|c|}
\hline $\begin{array}{c}\text { Sr. } \\
\text { No. }\end{array}$ & Soil groups & $\begin{array}{c}\text { Total } \\
\text { samples }\end{array}$ & $\mathbf{p H}$ & $\begin{array}{c}\mathbf{E C} \\
\left(\mathbf{d S m}^{-1}\right)\end{array}$ & $\begin{array}{c}\mathbf{O C} \\
\left(\mathbf{g k g}^{-\mathbf{1}} \mathbf{)}\right.\end{array}$ & $\begin{array}{c}\mathbf{C a C O}^{-1} \\
\left(\mathbf{g k g}^{-1}\right)\end{array}$ \\
\hline $\mathbf{1}$ & TypicHaplusterts & 44 & $7.71-$ & $0.18-$ & $2.18-$ & $15-82$ \\
& & & 8.30 & 1.37 & 9.97 & $(52.51)$ \\
& & & $(7.97)$ & $(0.34)$ & $(6.78)$ & \\
\hline $\mathbf{2}$ & VerticUstochrepts & 40 & $7.53-$ & $0.15-$ & $2.30-$ & $17.4-84$ \\
& & & 8.39 & 0.45 & 9.97 & $(54.22)$ \\
\hline $\mathbf{3}$ & Lithic Ustorthents & 26 & $7.95)$ & $(0.26)$ & $(6.68)$ & \\
\hline & & & 8.05 & 0.38 & 9.90 & $(52.31)$ \\
& & & $(7.79)$ & $(0.23)$ & $(7.40)$ & \\
\hline
\end{tabular}

(Figures in parentheses indicates average) 
Table.5 Categorization of soils on the basis of ratings of $\mathrm{pH}, \mathrm{EC}, \mathrm{CaCO}_{3}$ and organic carbon content

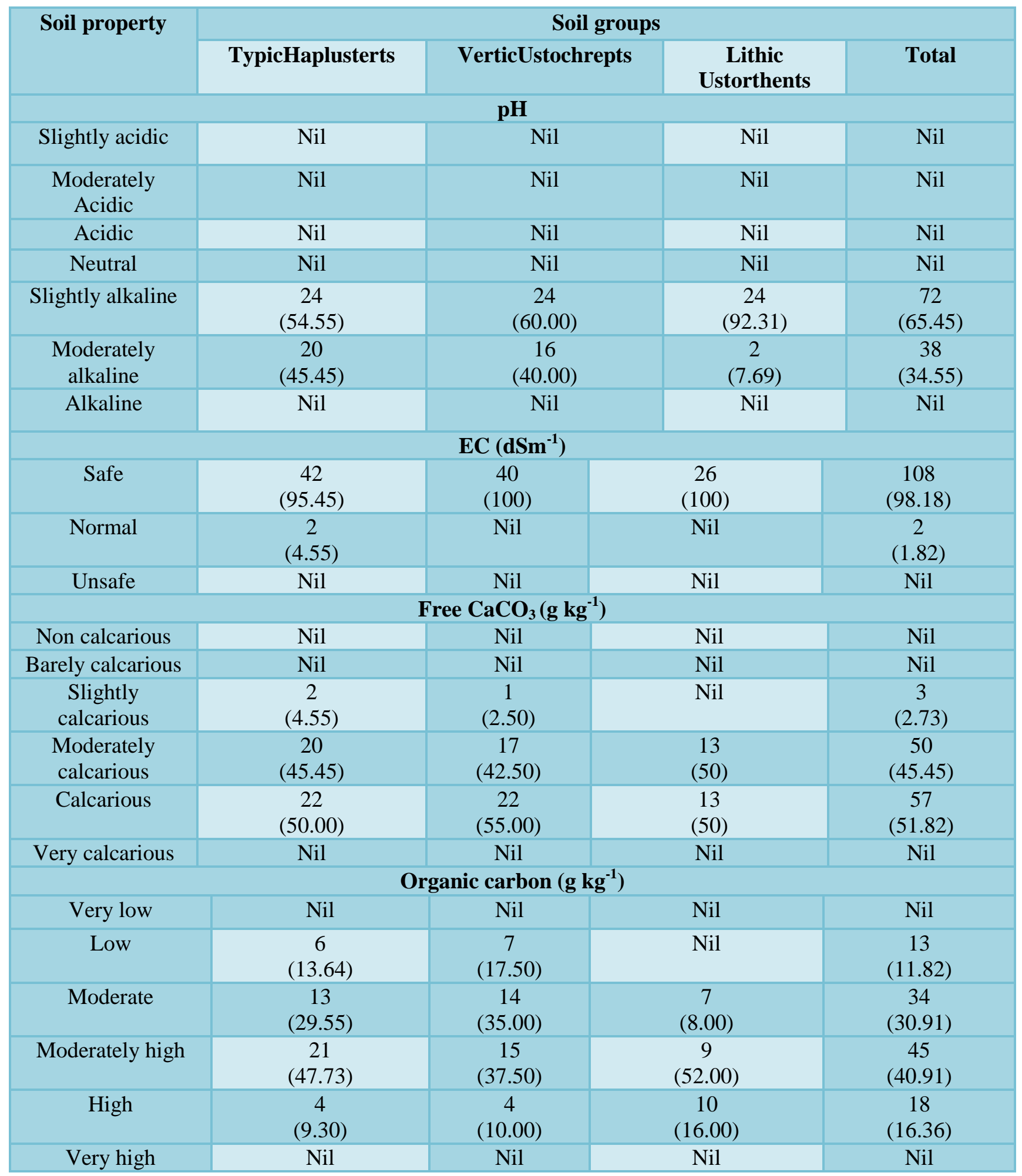

(Figures in parentheses indicates percentages) 


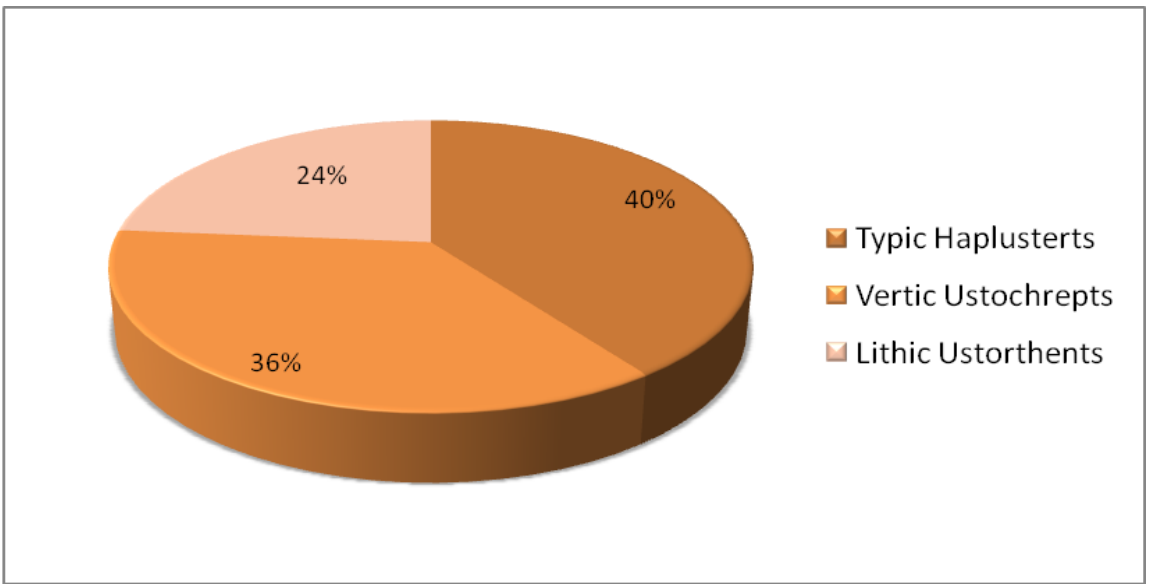

Fig.1 Distribution of soil samples of BSP Farm (Khanapur Block-B), MKV, Parbhani as per USDA Soil classification

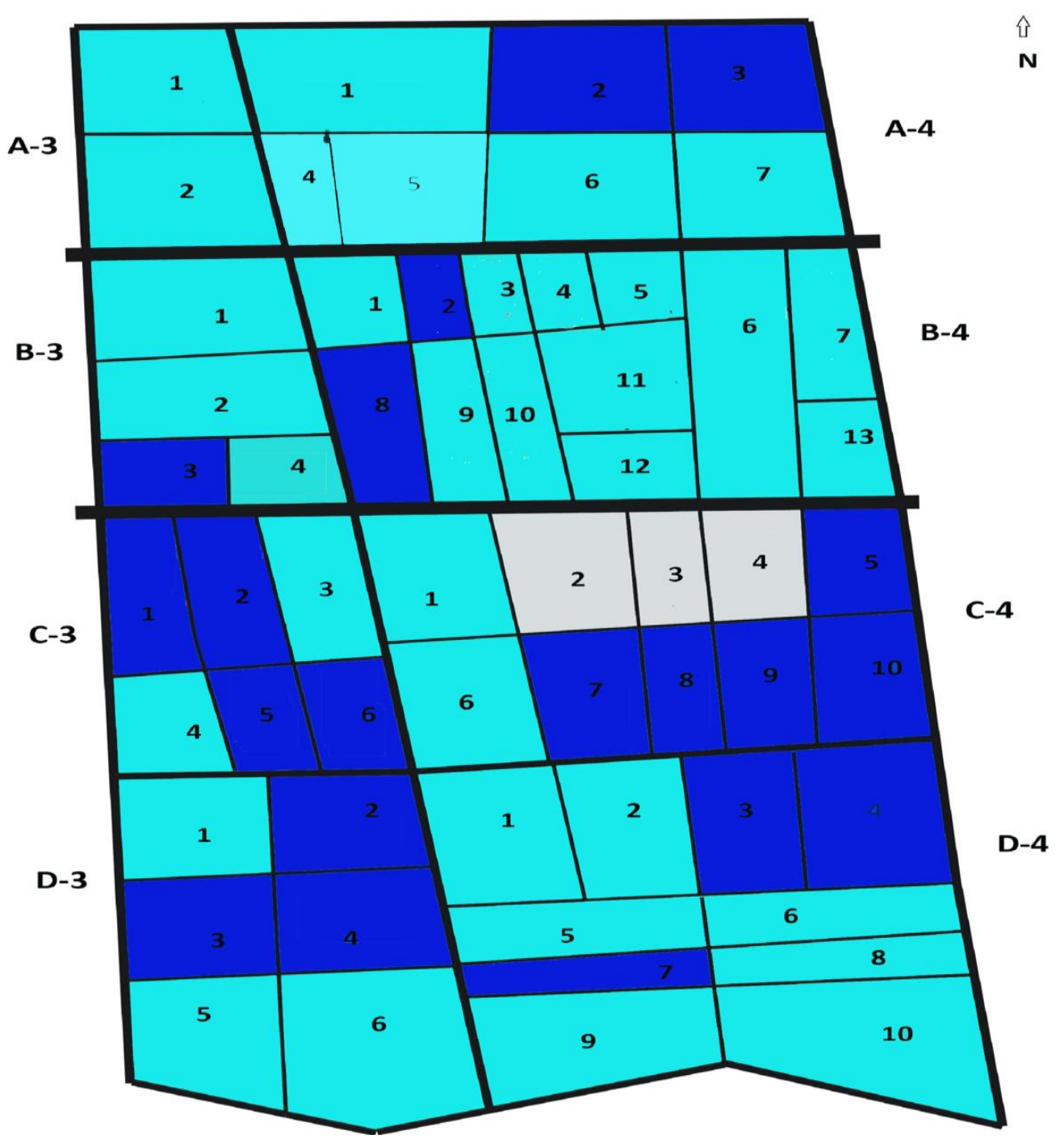

Fig.2 pH status of BSP farm (Khanapur Block-B), MKV, Parbhani 

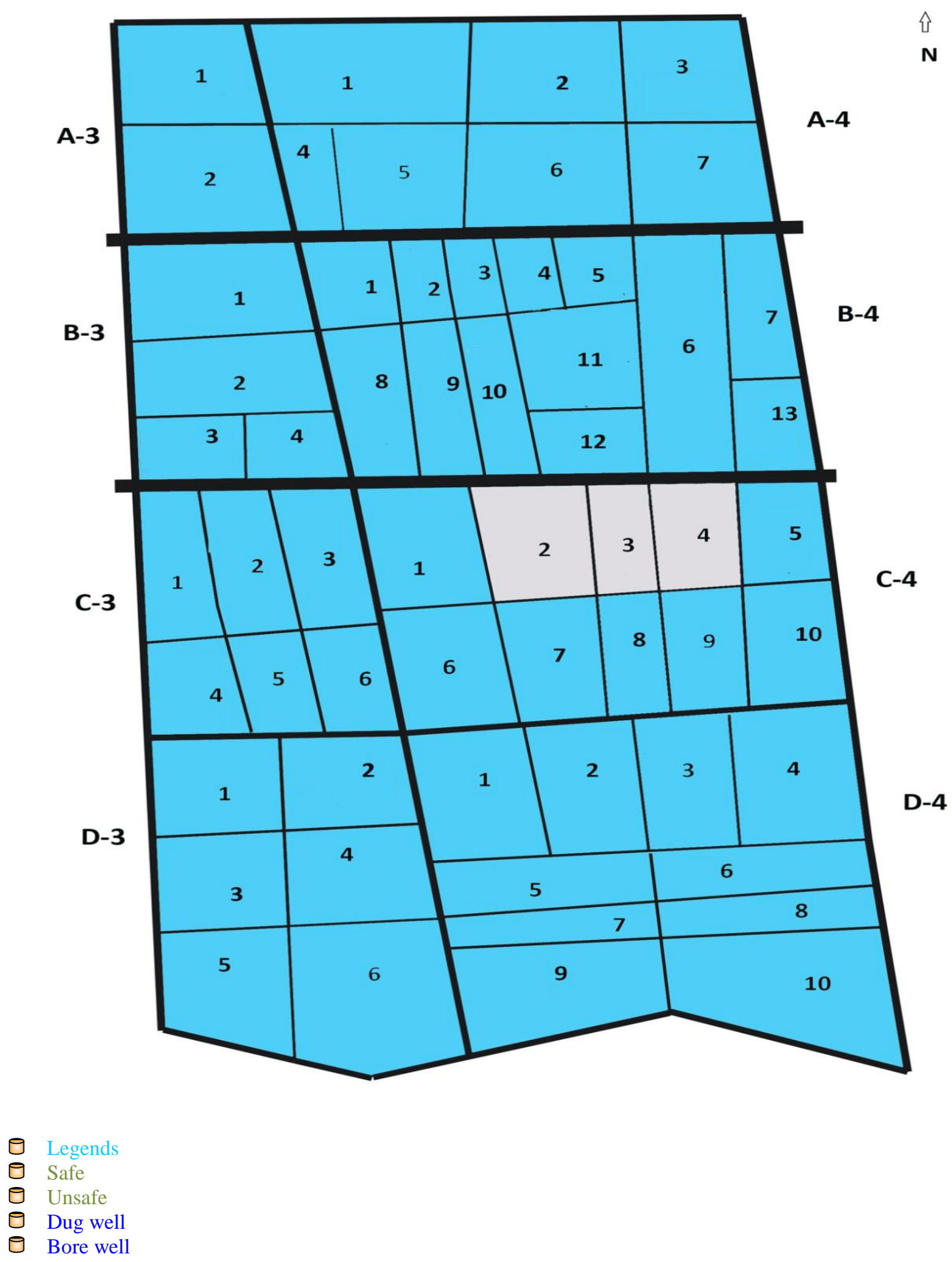

Fig.3 EC status of BSP farm (Khanapur Block-B), MKV, Parbhani 


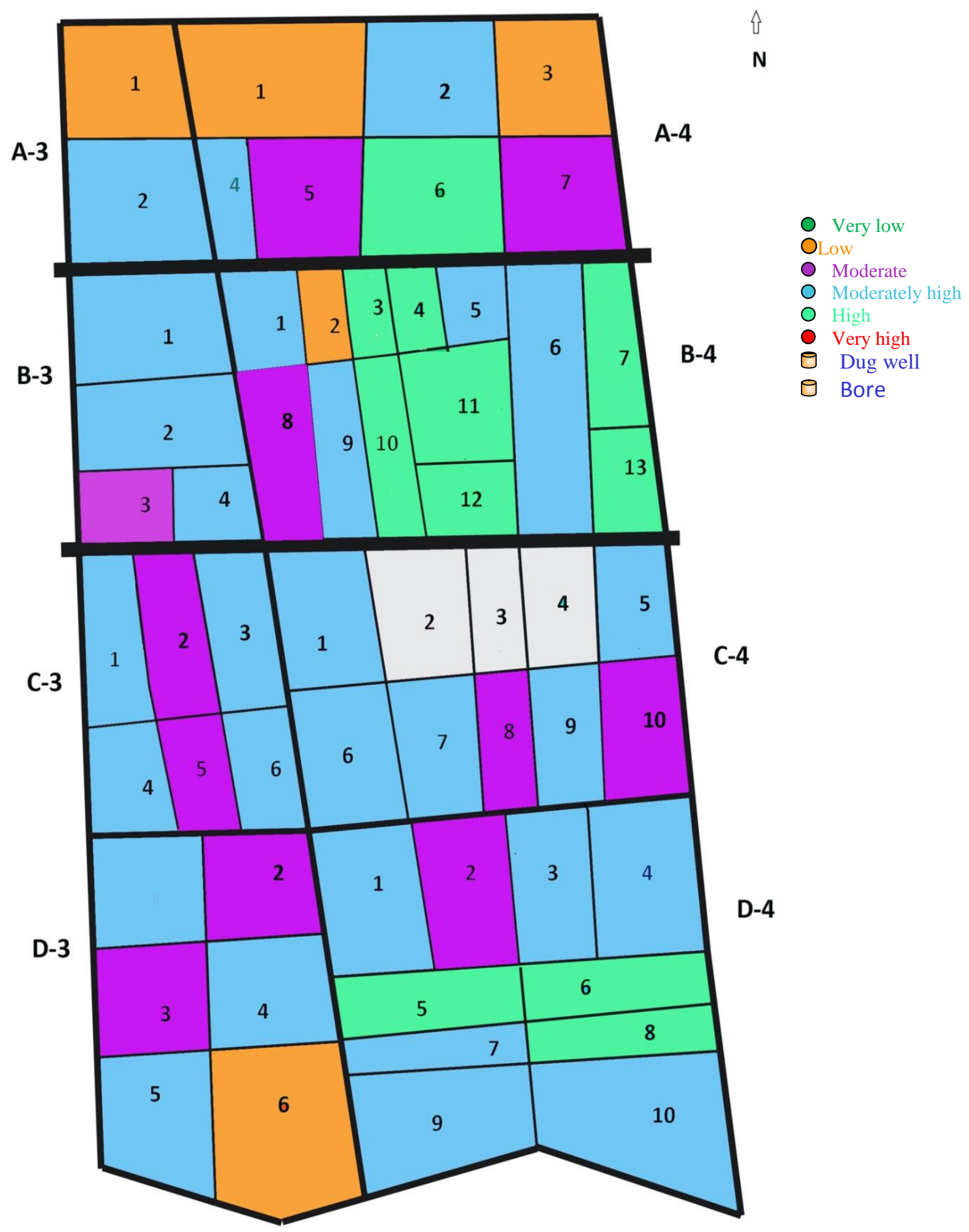

Fig.4 Organic carbon status of BSP farm (Khanapur Block-B), MKV, Parbhani 


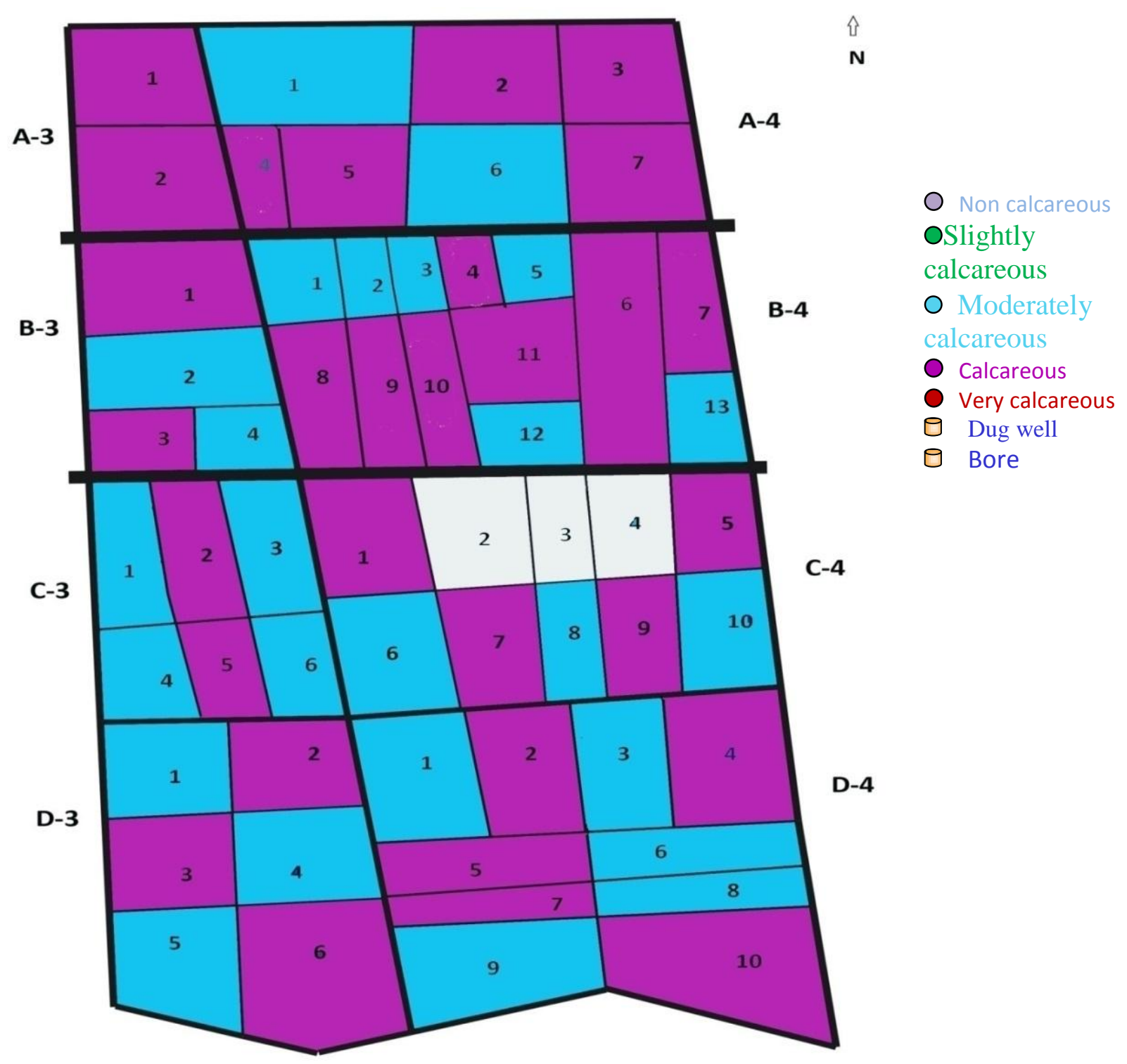

Fig.5 Free calcium carbonate status of BSP farm (Khanapur Block-B), MKV, Parbhani

The soils of BSP farm (Khanapur block-B) are deep to shallow and 3 dominate in TypicHaplusterts (23 plots) followed by VerticUstochrerts (19 plots) and Lithic Ustorthents (13 plots). According to Munsellcolour chart these soils are dark brown to black in colour. While, The bulk density of soils ranged from 1.30 to $1.48 \mathrm{Mgm}^{-3}$. The Entisols had higher bulk density than the Vertisols and Entisols. All soils are having clay texture derived from fine crystalline extrusive basalt rocks.

The soils are slightly alkaline (72 per cent) to moderately alkaline (38 per cent) in reaction. Among these three soil groups VerticUstochrepts showed higher $\mathrm{pH}$ than rest of soil groups. The soils are safe in total soluble salt concentration.

These soils are only 3 percent slightly calcareous, 45 percent moderately calcareous and 52 percent calcareous in nature. The soils $\mathrm{pH}, \mathrm{EC}$ and $\mathrm{CaCO}_{3}$ content was increased with depth. Soils content low to high in organic carbon. The VerticUstochrerts show lower organic carbon than TypicHaplusterts 
and Lithic Ustorthents. The thematic maps of important soil properties were generated, which are useful for better understanding and developing the location specific crop production technology on spatial basis of BSP farm (Khanapur Block-B).

The soils are shallow to deep, clayey, dark brown to black in colour.

The farm soils are slightly to moderately alkaline in reaction and safe in salt concentration, moderately calcareous $(\sim$ 46 per cent) to calcareous ( 53 per cent) in nature. These parameters are increased with depth of soil profile.

Variations were seen in the organic carbon content in soils of BSP farm (Khanapur Block-B).

On spatial basis thematic maps will be useful to optimize the fertilizer input to the soils for the overall balanced nutrition and also for sustainable crop production.

\section{References}

Bodhale A. A.(2007) Soil resource mapping of demonstration farm of

Das D. K., S. Bandopadhyay, D. Chakraborty and Rajeev Srivastava (2009) application of modern techniques in characterization and management of soil and water resources. $J$. Indian Soc. Soil Sci., 57(4): 445-460.

Ghuge, S. D., (2002) Effect of continuous cropping of sugarcane on micronutrient status in soils from Purna Sugar Factory area. M. Sc. Thesis. Marathwada Agricutural University, Parbhani

Jackson, M.L. (1973). Soil chemical analysis. Prentice Hall of India Ltd., New Delhi.

Jones, J.B. JR (1980) Handbook on references methods for soil testing. Council on soil testing and plant analysis Athens, Georgia.

Kanwar, J.S. and Randhwa, N.S.(1960). Probable cause of citrus chlorosis in Punjab. Hort. Adv., 4: 61-67.

Malewar G.U. (1986) Soil requirement of citrus paper presented in summer institute of citriculture held at MAU Parbhani. From $10^{\text {th }}$ November 1986 to $1^{\text {st }}$ Dec. 1986. Medhe S.R., Takankhar V.G. and Salve A.N. (2012). Correlation of chemical properties, secondary nutrients and micronutrient anions from the soils of chakurtahsil of Latur District, Maharashtra. www.sciencejournal.in ISSN Vol.1 (2) : 3440

MAU, Parbhani. M.Sc. (Agri.) Thesis, MAU, Parbhani.

Panse,V.G., and Sukhatme, P. N. (1985). Statistical methods for agricultural workers. IARI, New Dehli: 145-156.

Parker, F. W. (1951). Nutrient indices and preparation of soil fertility map.

SarkarDipak, U. Baruah, Gangopadhyay S. K., Sahoo, A. K. and Velayutham, M. (2002). Characterization and Classification of Catchment area of Manjpur for sustainable land use planning. J. Indian Soc. Soil. Sci.50 (2): 196-204.

Soniya, Thakare and Ingle (2010) Studies on soil properties of Jalgaon District. J. Soils and Crops. 20 (2) 301-306.

Todkari G.U., Suryawashi S.P., Suryawanshi M.V. and Patil B.D. (2010) Agriculture land use pattern in Solapur district of Maharashtra. Indian J. Agric. Science. Vol. 2(2): 01-08.

Vasekar Nilesh., (2001) Studies on sulphur fraction and their relationship with properties of soils of Basaltic orgin. M.Sc. (Agri.) Thesis, MKV, Parbhani.

Waghmare M.S., B.S. Indulkar, C.V. Mali, V.G.Takankhar and V.G. Bavalgave (2008). Chemical properties and micronutrient status of some soils of Ausatahsil of Latur, Maharashtra. An Asian J. Soil Science, Vol. 3, No.2: 236241.

Yadav Y.B. (2005) soil resource mapping of agricultural college farm, Latur. M.Sc. thesis. Marathwada agriculture university, Parbhani.

Yadav, D. V. and Khanna, S. S. (1979). Practical manual for introductory courses in soils. HAU, Hissar, pp 35-36. 


\section{How to cite this article:}

Shilewant, S. S., V. D. Patil and Gourkhede, P. H. 2020. Taxonomic Classification, Characterization and Mapping of BSP Farm of Parbhani for Rational Land Use Planning. Int.J.Curr.Microbiol.App.Sci. 9(04): 2808-2826. doi: https://doi.org/10.20546/ijcmas.2020.904.330 